\title{
HIGH PURE SUBSTANCES FOR ASTROPHYSICAL RESEARCH
}

\author{
G.P. Kovtun ${ }^{1,2}$ \\ ${ }^{1}$ National Science Center "Kharkov Institute of Physics and Technology”, \\ Kharkiv, Ukraine; \\ ${ }^{2}$ V.N. Karazin Kharkiv National University, Kharkiv, Ukraine \\ E-mail: gkovtun@kipt.kharkov.ua
}

The features of the application of high-purity substances for studying rare nuclear events in astrophysics, in particular double beta decay, are considered. It was noted that for such studies, the special underground laboratories are needed to eliminate the cosmic radiation background, and the use of high-purity materials for possibility to record rare nuclear events. The content of neutral impurity elements should not exceed $0.1 \mathrm{ppm}$, and the level of radionuclide contamination should be less than units $\mathrm{mBq} / \mathrm{kg}$. At the NSC KIPT, the technologies have been developed for the production of high-purity refractory (W, Mo, Re, Ru, Os) and low-melting metals ( $\mathrm{Zn}, \mathrm{Cd}, \mathrm{Te}$, ${ }^{\text {arch }} \mathrm{Pb}$ ), including isotopically-enriched ${ }^{106} \mathrm{Cd},{ }^{116} \mathrm{Cd}$, satisfying these requirements. Using these metals both as individual elements and as part of low-background scintillation single crystals, it was possible to obtain a number of new fundamental results in the field of astrophysics, together with the Institute for Nuclear Research of the National Academy of Sciences of Ukraine and the Gran Sasso Laboratory of the National Institute of Physics (Italy).

PACS: 23.40.-s; 29.40.Mc; 81.20.Ym

It is widely known the use of high-purity substances, including metals, in various fields of engineering. First of all, it is nuclear power engineering, electronics, fiber optics. Recently, high-purity metals find an application for microelectronics, medicine and other areas. The main motivating stimulus in this direction is the need to create materials with new physical and mechanical properties. At the same time, very often the motivation for production of high-purity substances is the striving for basic research. Recently, investigations in the range of astrophysics, i.e. in the field of studying elementary particles of cosmological origin in order to expand our conceptions about the World around us have been developing. The "ordinary" material world actually observed at the present time is about $4 \%$ of the actual material world of the Universe. The rest of the material world of the Universe is attributed to the so-called dark energy $(74 \%)$, dark matter $(22 \%)$, about the nature of which there are very vague ideas. The main efforts are aimed at explaining the composition of the Universe, in particular, the nature of dark matter, dark energy; study of the properties of neutrinos and its importance in the development of the Universe; investigation of cosmic radiation; the searches for gravitational waves and various effects outside the standard model of elementary particles.

Dark matter in astronomy and cosmology is a form of matter that does not emit electromagnetic radiation and does not interact with it. This property of this form of matter makes it impossible to observe it directly. It is assumed that it consists of new particles that have not yet been discovered under terrestrial conditions, which are $100 \ldots 1000$ times heavier than the proton, and that their interaction with ordinary matter is comparable in intensity with the interaction of neutrinos [1]. The matter of the nature of dark energy is even more obscure. Dark energy in cosmology is a type of energy, introduced into the mathematical model of the Universe in order to explain its observed accelerating expansion. The nature of dark energy is the main mystery of fundamental physics of the 21 st century.
To explain the composition of the Universe, it is extremely important to study the properties of the neutrino and its importance in the development of the Universe. The properties of neutrinos play an important part in ascertaining the most interesting mysteries of the Universe - the nature of dark matter (neutrino is the only identified component of this mysterious substance) and baryonic asymmetry [2, 3]. To present time, there is convincing evidences of neutrino oscillations, which indicate the presence of nonzero masses in neutrinos. However, oscillation experiments are not able to determine the magnitude of the neutrino mass. The most sensitive and direct way to study the nature of a certain type of neutrino (Majorana or Dirac) is to search for neutrinoless double $\beta$-decay ( 0 v2 $\beta$-decay) [1-4].

Double $\beta$-decay is the general name of several types of radioactive decay of an atomic nucleus, as a result of which the nuclear charge changes (increases, decreases) by two units

$$
(\mathrm{A}, \mathrm{Z}) \rightarrow(\mathrm{A}, \mathrm{Z}+2)+2 \mathrm{e}^{-}+2 v_{\mathrm{e}} .
$$

This is the rarest radioactive decay of all decays. All 11 nuclides for which this process was reliably observed have a half-life within the range of $10^{18} \ldots 10^{24}$ years, which is by several orders of magnitude longer than the lifetime of the Universe. There are two types of $2 \beta$ decay:

- two-neutrino $2 \beta$ decay $(2 v 2 \beta)$ in which two neutrinos are emitted in the final state (found in 11 elements);

- neutrinoless $2 \beta$-decay $(0 v 2 \beta)$ in which neutrino is not emitted (not detected).

The detection of at least one example of a neutrinoless mode ( $0 v 2 \beta$ decay) will mean a revision of the provisions of the standard model. However, to date, only lower limitations on the half-lives of $0 v 2 \beta$ decay, which reach $10^{25}$ years, have been obtained. It corresponds to the upper limitation on the Majorana neutrino mass of about $0.4 \mathrm{eV}$.

The main difficulty encountered in carrying out the experiments on the study of $2 \beta$ decay is caused by the low probability of the event, the need for long-term 
experiments and maximum reduction in background events as well as for a thorough analysis of the results.

The search for double $\beta$ decay is one of the priority tasks of modern physics. It is due to the fact that just during the investigation of $2 \beta$ decay one can obtain information about the absolute mass scale and the scheme of mass states of neutrino, check the law of lepton charge conservation, find out the nature of the neutrino (Dirac or Majorana particle) and a number of other effects outside the standard model of elementary particles.

Experiments on recording rare nuclear events (dark matter particles, $2 \beta$ decay, etc.) require at least two conditions to be fulfilled: carrying out experiments deep underground to reduce the radiation background of cosmic rays, and producing high-purity substances to create low-background high-sensitivity detectors and protective materials shielding against residual radiation exposure of the environment. To achieve good scintillation properties of the detector, the content of many impurity elements must be $<0.1 \mathrm{ppm}$. Even more stringent requirements are imposed on the radioactive purity of the detector. The content of a number of natural radionuclides should be $<0.1 \ldots 0.01 \mathrm{ppb}$, and that of the uranium-thorium chain should be $<1.0 \ldots 0.1 \mathrm{ppt}$.

More than 20 underground laboratories, located at depths from hundreds of meters to $2 \mathrm{~km}$, have been formed in the world to carry out experiments underground. One of the largest is the Gran Sasso National Laboratory, one of the four laboratories of the Italian National Institute of Nuclear Physics. The laboratory consists of a ground part and underground premises located at an average depth of about $1400 \mathrm{~m}$ (3600 $\mathrm{m}$ of water equivalent) and at an altitude of about $1000 \mathrm{~m}$ above sea level.

The underground part of the laboratory consists of three large halls connected by underground tunnels. Each hall has a length of $100 \mathrm{~m}$, a width and a height of about $20 \mathrm{~m}$. Access to the underground halls of the laboratory is through a car tunnel with a long of more than $10 \mathrm{~km}$. The underground arrangement allows reducing the background of cosmic radiation by many orders of magnitude.

Research in the Gran Sasso laboratory is carried out in two main areas:

- study of the properties and interactions of neutrinos, which includes the search for $2 \beta$ decay;

- search for the particles of which dark matter could consist.

Three large detectors are currently registering neutrinos: Borexino, LVD, OPERA. These are complex, massive buildings made of very pure materials, measured in hundreds and thousands of tons, with liquid scintillators for detecting neutrino flares and other rare nuclear events. In the OPERA experiment, neutrinos are detecting, the beam of which is directed to Gran Sassofrom CERN (Switzerland). A neutrino beam travels $730 \mathrm{~km}$ inside the Earth before it reaches the detector.

The detection of such "elusive" particles as neutrinos is complicated by natural radioactivity which always present to some extent in any materials and imitating the processes of neutrino interaction. The degree of purity of the materials used in the detectors is amazing. So, as a result of long-term development of technologies for removal of natural radioactive impurities from liquids and gases, the fantastic results were achieved: in every gram of the substance with which the neutrino interacts, only $10^{-17} \mathrm{~g}\left(10^{-15} \%\right)$ of extraneous impurities are contained. For example, the nitrogen used in the experiments has a radioactivity by billion times less than that of natural nitrogen. A similar level of radionuclide contamination is also characteristic of other materials of the detector. There is no doubt that the developed new technologies will have a huge impact on the pharmaceutical industry, the nanomaterials industry and the technology for the production of newgeneration electronic components.

Recently, solid-state scintillation detectors have been used as detectors for recording rare nuclear events. The scintillation method is promising that for the study of $2 \beta$ decay owing to the availability of scintillators containing elements that have potential $2 \beta$-active isotopes. In addition, it is possible to investigate several nuclei simultaneously, identify $\alpha$ and $\beta$ particles, and ensure stability of operation for long periods (years).

The most promising by luminescent and scintillation properties as the detectors for recording rare nuclear events are the following scintillation materials: $(\mathrm{Cd}$, $\left.{ }^{106} \mathrm{Cd},{ }^{116} \mathrm{Cd}\right) \mathrm{WO}_{4},\left(\mathrm{Zn},{ }^{64} \mathrm{Zn},{ }^{70} \mathrm{Zn}\right) \mathrm{WO}_{4}, \mathrm{PbWO}_{4},(\mathrm{Cd}$, $\left.{ }^{106} \mathrm{Cd},{ }^{116} \mathrm{Cd}\right) \mathrm{MoO}_{4},\left(\mathrm{Zn},{ }^{64} \mathrm{Zn}\right) \mathrm{MoO}_{4}, \mathrm{PbMoO}_{4}, \mathrm{MgWO}_{4}$, $\mathrm{CaF}_{2}, \mathrm{MgF}_{2}, \mathrm{ZnSe}$ etc. In order to get crystals with high scintillation characteristics, it is necessary to implement the control of the purity of the initial materials and the mixture at the level of $<0.1 \mathrm{ppm}$ for a number of impurities. To ensure radionuclide purity, it is necessary to control radioactive impurities at the level of $\mu \mathrm{Bq} / \mathrm{kg}$ $\left({ }^{228} \mathrm{Th}\right.$ and ${ }^{226} \mathrm{Ra}$ ) and units of $\mathrm{mBq} / \mathrm{kg}$ ( $\alpha$-active elements U/Th).

The production of scintillators made of enriched isotopes can significantly increase the sensitivity of experiments for the search for double $\beta$-decay.

The sensitivity of solid-state scintillators increases significantly when they contain isotopically enriched elements capable to be subjected to $2 \beta$ decay. The sensitivity of determining the half-life of $2 \beta$ decay is directly proportional to the isotopic content relative to the parent nuclide.

Therefore, the enrichment of the investigated material with the necessary isotope by an order of magnitude leads to a proportional increase in the sensitivity of the experiment. For example, natural cadmium consists of eight stable isotopes: ${ }^{106} \mathrm{Cd}(1.22 \%), \quad{ }^{108} \mathrm{Cd}(0.88 \%), \quad{ }^{110} \mathrm{Cd}(12.39 \%)$, ${ }^{111} \mathrm{Cd}(12.75 \%), \quad{ }^{112} \mathrm{Cd} \quad(24.07 \%), \quad{ }^{113} \mathrm{Cd}(12.26 \%)$, ${ }^{114} \mathrm{Cd}(28.85 \%)$, and ${ }^{116} \mathrm{Cd}(7.58 \%)$. The nuclei of two isotopes of this set $-{ }^{106} \mathrm{Cd}$ and ${ }^{116} \mathrm{Cd}$ undergo by double beta decay, in connection with that the special interest is caused precisely in these isotopes.

NSC KIPT has developed complex methods for the production of a number of high-purity refractory (W, Mo, $\mathrm{Re}, \mathrm{Ru}, \mathrm{Os})$ and low-melting metals ( $\mathrm{Zn}, \mathrm{Cd}, \mathrm{Te}$, ${ }^{\text {arch }} \mathrm{Pb}$ ), including isotopically enriched ${ }^{106} \mathrm{Cd}(65 \%)$, ${ }^{116} \mathrm{Cd}(81 \%)$, for investigations of $2 \beta$ decay $[5,6]$. The use of high-purity metals made it possible to produce (at 
the Institute of Scintillation Single Crystals of NASU, Institute of Inorganic Chemistry, Novosibirsk, Russia) a number of scintillation single crystals of unprecedented high quality $\left(\mathrm{ZnWO}_{4}, \mathrm{CdWO}_{4},{ }^{106} \mathrm{CdWO}_{4},{ }^{116} \mathrm{CdWO}_{4}\right.$, $\mathrm{PbWO}_{4},{ }^{\text {arch }} \mathrm{PbWO}_{4}, \mathrm{PbMoO}_{4} \mathrm{Zn}^{82} \mathrm{Se}$ etc.), on the basis of which the low-background scintillation detectors were created to record various rare nuclear events.

As a result of recent experiments using high purity $\mathrm{Zn},{ }^{116} \mathrm{Cd},{ }^{106} \mathrm{Cd},{ }^{\text {arch }} \mathrm{Pb}, \mathrm{W}, \mathrm{Ru}$, Os both in the form of individual elements and as a part of low-background scintillation single crystals, together with the Institute for Nuclear Research of the NAS of Ukraine and the Grant Sasso Laboratory of the National Institute of Physics (Italy), a number of new fundamental results were obtained:

- $2 \beta$ decay in $\mathrm{Zn},{ }^{116} \mathrm{Cd}$, ${ }^{\text {arch }} \mathrm{Pb}, \mathrm{W}, \mathrm{Ru}$, Os was studied at the new level of sensitivity;

- restrictions on the neutrino mass are established at the level of $0.3 \ldots 0.7 \mathrm{eV}$;

- neutrino flux was first measured as a result of the decay of ${ }^{7} \mathrm{Be}$ nuclei under the influence of sunlight;

- antineutrinos emitted from the depths of the Earth were recorded;

- studies of rare $\alpha$-, $\beta$-decays of atomic nuclei were performed.

Recently, the first stage of the search for neutrinoless $2 \beta$-decay occurring on $\mathrm{Zn}^{82} \mathrm{Se}$ crystals has been performed. A zinc selenide crystal was produced at the Institute of Scintillation Single Crystals of NASU, and high-purity zinc did at the NSC KIPT Investigations had been performed using a cryogenic bolometric technique [7]. The cryogenic bolometer consisted of an absorbing material cooled to a very low temperature (about 10...20 mK) and a thermometer capable of measuring the temperature increase at a very low energy of recoil of interacting particles to the absorber. If the absorbing material is also a scintillator, then this makes it possible to distinguish interacting particles of various types by changing the ratio of light to heat. Thin plates of the high-purity germanium isotope ${ }^{76} \mathrm{Ge}$ were used as bolometric light detectors. The preliminary experiments made it possible to fix the inferior limitations on the half-life of the $0 v 2 \beta$ decay of ${ }^{82} \mathrm{Se}$, which is $>3.5 \cdot 10^{24}$ years [8].

The scientific goal of these studies was not only to search for $2 \beta$ decay, but also to lay the foundation for the next generation experiment which fully utilizes the innovative potential of this new method.

\section{CONCLUSIONS}

Recently, the investigations have been intensively developing in the area of particle astrophysics in order to expand our conceptions about the World around us. Development of the particle astrophysics requires the elaboration of scintillation materials having low degree of radioactive contamination, containing certain elements, as well as possessing parameters which are at the limit of possibilities of modern technologies. Scintillators made of enriched isotopes take a special place, and allow significantly increase the sensitivity of experiments aimed at searching for $2 \beta$ decay. Despite the large material costs, new underground laboratories are being created in many countries and new detectors are being developed to study the nature of neutrinos and record rare nuclear events in astrophysics.

\section{REFERENCES}

1. F.A. Danevich. Scintillators in particle astrophysics // Proceedings Int. Conf. "Engineering of Scintillation Materials and Radiation Technologies". Kharkiv: ISMA, 2009, p. 54-92.

2. A.S. Barabash. Double beta decay experiments: current status and prospects // Phys. Usp. 2014, v. 57, issue 5, p. 482-488.

3. F.A. Danevich. Investigation of Neutrino and Weak Interactions in Double Beta Decay of Atomic Nuclei. In Ukrainian // Visnyk of NAS of Ukraine. 2015, N 9, p. 39-47.

4. F.A. Danevich, V.V. Kobychev, V.I. Tretyak. Neutrinos are Massive. Nobel Prize in Physics 2015 // Visnyk of NAS of Ukraine. 2016, N 91, p. 20-29.

5. V.M. Azhazha, G.P. Kovtun, G.F. Tihinsky. Production and metallophysics of highly pure metals // Metallophysics and Advanced Technologies. 2000, v. 22, N 2, p. 21-35.

6. G.P. Kovtun, A.P. Shcherban', D.A. Solopikhin, V.I. Zelenskaya, F.A. Danevich, R.S. Boiko, S.S. Nagorny. High-purity substances for the development of low-background scintillators. In Russian // Perspektivnye materialy, special issue. 2011, p. 1-6.

7. L. Gironi. Scintillating bolometers for Double Beta Decay search // Nucl. Instrum. Meth. A: Accelerators, Spectrometers, Detectors and Associated Equipment. 2010, v. 617, N 1-3, p. 478-481.

8. O. Azzolini, J.W. Beeman, F. Bellini, et al. Final result of CUPID-0 phase-I in the search for the ${ }^{82} \mathrm{Se}$ Neutrinoless Double Beta Decay // Phys. Rev. Lett. 2019, v. 123, N 3, p. 032501.

Article received 18.11.2019

\section{ВЫСОКОЧИСТЫЕ ВЕЩЕСТВА ДЛЯ АСТРОФИЗИЧЕСКИХ ИССЛЕДОВАНИЙ}

\section{Г.П. Ковтун}

Рассмотрены особенности применения высокочистых веществ для исследования редких ядерных событий в астрофизике, в частности двойного $\beta$-распада. Отмечено, что для проведения подобных исследований необходимы специальные подземные лаборатории для устранения фона космических излучений и применение высокочистых материалов для возможности регистрации редких ядерных событий. Содержание нейтральных примесных элементов при этом не должно превышать 0,1 ррт, а уровень радионуклидного загрязнения - менее единиц мБк/кг. В ННЦ ХФТИ были разработаны технологии получения высокочистых тугоплавких (W, Mo, Re, Ru, Os) и легкоплавких ( $\left.\mathrm{Zn}, \mathrm{Cd}, \mathrm{Te},{ }^{\text {apx }} \mathrm{Pb}\right)$ металлов, в том 
числе изотопно-обогащенных ${ }^{106} \mathrm{Cd},{ }^{116} \mathrm{Cd}$, удовлетворяющих этим требованиям. С использованием этих металлов как в виде отдельных элементов, так и в составе низкофоновых сцинтилляционных монокристаллов совместно с Институтом ядерных исследований НАН Украины и лабораторией Гран-Сассо Национального института физики (Италия) удалось получить ряд новых принципиальных результатов в области астрофизики.

\section{ВИСОКОЧИСТІ РЕЧОВИНИ ДЛЯ АСТРОФІЗИЧНИХ ДОСЛІДЖЕНЬ}

\section{Г.П. Ковтун}

Розглянуто особливості застосування високочистих речовин для дослідження рідкісних ядерних подій в астрофізиці, зокрема подвійного $\beta$-розпаду. Відзначено, що для проведення подібних досліджень необхідні спеціальні підземні лабораторії для усунення фону космічних випромінювань і застосування високочистих матеріалів для можливості реєстрації рідкісних ядерних подій. Вміст нейтральних домішкових елементів при цьому не повинен перевищувати $0,1 \mathrm{ppm}$, а рівень радіонуклідного забруднення - менше одиниць мБк/кг. У ННЦ ХФТІ були розроблені технології отримання високочистих тугоплавких (W, Mo, Re, Ru, Os) i легкоплавких ( $\left.\mathrm{Zn}, \mathrm{Cd}, \mathrm{Te},{ }^{\text {apx }} \mathrm{Pb}\right)$ металів, у тому числі ізотопно-збагачених ${ }^{106} \mathrm{Cd},{ }^{116} \mathrm{Cd}$, що задовольняють цим вимогам. 3 використанням цих металів як у вигляді окремих елементів, так і в складі низькофонових сцинтиляційних монокристалів спільно з Інститутом ядерних досліджень НАН України та лабораторією Гран-Сассо Національного інституту фізики (Італія) вдалося отримати ряд нових принципових результатів у галузі астрофізики. 